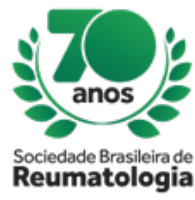

\title{
MILIARY TUBERCULOSIS DISSEMINATED SECONDARY TO USE OF ANTI-TNF IN A PATIENT WITH
} CHRONIC ARTHRITIS

Letícia Lopes Coimbra (Hospital Geral de Palmas. Universidade Federal do Tocantins., Palmas, TO, Brasil), Tayanne Fonseca Rodrigues (Hospital Geral de Palmas., Palmas, TO, Brasil), Maria Eduarda Guimarães Leal (Hospital Geral de Palmas. Universidade Federal do Tocantins. , Palmas, TO, Brasil), Allethéa Robertha Souza e Silva (Hospital Geral de Palmas., Palmas, TO, Brasil), Danilo Garcia Ruiz (Hospital Geral de Palmas. Universidade Federal do Tocantins., Palmas, TO, Brasil), Paulo Geovanny Pedreira (Hospital Geral de Palmas., Palmas, TO, Brasil), Daniela Maria Edilma Japiassú Custódio (Hopital Geral de Palmas., Palmas, TO, Brasil), Paola Bottin Madrid (Hospital Geral de Palmas., Palmas, TO, Brasil), Hugo de Carlos Maciel Rossoni (Hospital Geral de Palmas., Palmas, TO, Brasil), Rafaela Alen Costa Freire (Hospital Geral de Palmas., Palmas, TO, Brasil)

\section{BACKGROUND}

Tuberculosis (TB) is a disease of high incidence and prevalence. It is now known that the risk of patients with rheumatoid arthritis (RA) presenting TB is 2 to 4 times higher than the general population. Tumor Necrosis Factor (TNF) is an inflammatory cytokine that plays an important role in the immune response against Mycobacterium tuberculosis. It acts by increasing the phagocytic capacity of macrophages, destroying the pathogen, promoting the formation of granuloma, and preventing it from spreading the disease. Thus, the use of anti-TNF in RA patients increases the risk of TB occurrence.

\section{CASE REPORT}

A. P. C., female, 26 years old, started headache and vomiting 7 days ago. There have been 3 months with afternoon fever, dry cough and respiratory discomfort. She has been a carrier of juvenile idiopathic arthritis for 20 years. He made use of Methotrexate which was replaced by Leflunomide due to gastric intolerance. Without remission, it was started three months the use of certolizumab with pre-biological examinations without changes (including PPD: $0 \mathrm{~mm}$ ). Physical examination revealed dehydrated and afebrile. Chest radiography with pleural effusion on the left. Performed thoracentesis with drainage of $930 \mathrm{ml}$ of fluid with exudative appearance, suspension of leflunomide and certolizumab, biopsy of the pleura, collection of sputum and tomography of thorax. Tomography with diffuse micronodules in lung parenchyma. The 1st BAAR sample had a negative result, and due to suspicion of miliary TB of paucibacillary character, patient was withdrawn from respiratory isolation and started RIPE scheme. Due suspected to the persistence of the headache, cerebrospinal fluid collection was performed, evidencing glucose consumption, lymphocytes increase and absence of microorganisms stained by the gram method. Being on this occasion started acyclovir. Subsequently, the diagnosis of pleural TB was confirmed with the pleural biopsy result. Due to CNS impairment the treatment was extended to 12 months.

\section{CONCLUSION}

The patient was treated similarly to rheumatoid arthritis in adults. After failure of Methotrexate and Leflunomide, an anti-TNF was associated and developed tuberculosis. In view of the above, the patient developed extrapulmonary TB with pleural and meningeal involvement during the first months of immunobiological therapy, even after screening for ILTB as recommended by the Ministry of Health protocol. Studies show that patients with RA who had TB presented an extrapulmonary pattern in $60 \%$ of the cases and disseminated in $26 \%$. This case is reported because of the unusual extent of involvement. 